\title{
Energy poverty in the świętokrzyskie voivodeship during the Covid-19 pandemic - In the context of the cumulative causation theory

\author{
Katarzyna J. Chojnacka
}

Doctor, Faculty of Law and Social Sciences, Department of Economics and Finance, Jan Kochanowski University in Kielce, Poland.

Email: katarzyna.chojnacka@ujk.edu.pl

\author{
Keywords \\ Poverty, Energy, Households, Pandemic, Covid- \\ 19.
}

\section{Article History}

Received on $18^{\text {th }}$ January 2021

Accepted on $27^{\text {th }}$ January 2022

Published on $24^{\text {th }}$ February 2022

\section{Cite this article}

\section{Copyright @Author}

Chojnacka, K. J. (2022). Energy poverty in the świętokrzyskie voivodeship during the Covid-19 pandemic - In the context of the cumulative causation theory. Humanities \& Social Sciences Reviews, 10(1), 46-54. https://doi.org/10.18 $\underline{\text { 510/hssr.2022.1016 }}$

\section{Publishing License}

This work is licensed under a Creative Commons Attribution-Share Alike 4.0 International License cc) (7) (?)

\begin{abstract}
Purpose of the study: The purpose of this article is to answer the question: does changing the socioeconomic situation alter the households' condition and energy poverty level in a noticeable manner in the region? (with particular emphasis on the COVID-19 pandemic period).
\end{abstract}

Methodology: An inherent aspect of poverty is the limitation of the broadly defined development opportunities, both on economic, political, and social levels. Since economic poverty co-occurs with the phenomenon of energy poverty in households, the author posited the following thesis: there is a relationship between energy poverty and economic situation of households and health of its members in the region. The analysis will be based on: a study of household budgets, social diagnosis and available reports on energy poverty, and supplemented by an interpretation of an original survey conducted in the Świętokrzyskie voivodeship (conducted in mid-2021 for the previous two years).

Main Findings: Effectively combating energy poverty in the country and in a specific area (including the voivodeship) requires adequate recognition of the situation and identification of the people or households affected. The multifaceted nature of the phenomenon does not make it easy to choose which of the known indicators should be analyzed first. Moreover, its consequences vary as well. More details you will see at the conclusion.

Applications of the study: The article presents the phenomenon of energy poverty accompanying both social and economic life (the phenomenon of poverty should be considered multidimensionally). The social and health costs of energy poverty were emphasized. The content of the article can be useful for a wide group of recipients interested in the subject under research. Besides, this research is expected to be applied in Jan Kochanowski University during practical meetings with students.

Novelty/Originality of the study: The COVID-19 pandemic is having a noticeable impact on society and its members, individual markets, and the economy as a whole. Undeniably we have found ourselves in a difficult situation where numerous concepts are beginning to take on a deeper meaning. This includes energy poverty. In addition, there is no comprehensive research on the topic described in the title (for the Świętokrzyskie voivodeship) and the article tries to fill this gap. The article can inspire further research and inquiry in the field of it.

\section{INTRODUCTION}

An inherent aspect of poverty is the limitation of the broadly defined development opportunities, both on an economic, political and social level (Kumar, Nayar, 2020). Since economic poverty co-occurs with the phenomenon of energy poverty in households, the author posited the following thesis: There is a relationship between energy poverty and the economic situation of families and the health of its members. The purpose of this article is to answer the question: does change the socioeconomic situation alter the households' condition and energy poverty level in a noticeable manner in the region - mentioned in the title - with particular emphasis on the COVID-19 pandemic period? The social and health costs of energy poverty were emphasized. These words are the motto for considerations: “(...) there are, in reality, no economic problems, no psychological problems, no anthropological problems, there are just problems, and all these problems are very complex." (Myrdal, 1970, p. 10).

The analysis will be based on: a study of household budgets, social diagnosis, and available reports on energy poverty, and supplemented by an interpretation of an original survey conducted in the Świętokrzyskie voivodeship. The first part of the paper includes a definition and explanation of the phenomenon of poverty. It presents, i.a., the scope, severity, and intensity of poverty. The second part is focused on delivering G. Myrdal's theory in a manner enabling one to relate it to the poverty presented earlier. The final section addresses the hypothesis and purpose of the paper, preceding the conclusions with a brief analysis of available empirical data (from official statistic data and an author's survey). 


\section{THEORETICAL RATIONALE FOR ADDRESSING THE TOPIC}

The concept of energy poverty, although known since the 1980s, it is not clearly defined. Therefore, we shall assume that it is a phenomenon of experiencing difficulties in satisfying basic energy needs in the place of residence at a reasonable price, which consists of maintaining an adequate standard of heating and supply of other types of energy to adequately satisfy the basic biological and social needs of household members (Miazga, Owczarek, 2015, p. 6). It can result from low income as well as energy inefficiency of the place of residence or irrational management of household energy sources (Weglarz, Kubalski, Owczarek, 2014, p. 8). Prolonged difficulty in maintaining an optimal temperature can lead to respiratory illnesses, allergies (in the case of overly humid and fungal dwellings), and psychological well-being (stress, anxiety, lowered mood). These factors, in turn, can lead to a decline in immune function, endocrine disorders, or cardiovascular dysfunction (Stepniak, Tomaszewska 2014). As reported by R. Boguszewski and T. Herudziński (2018), at the stage of introducing the concept of energy poverty to the Polish legal order (Kubiczek, Hadasik, 2021), it was necessary to refer to the modeling of expenses in connection with the parameters of the place of residence. This is undoubtedly more difficult than analysis in absolute terms (where only the shares of energy expenditure in the income available to the household are determined).

Table 1: Leading causes of energy poverty and their consequences

\begin{tabular}{|c|c|c|}
\hline Type of causes & Impact on disposable income levels & Brief description of the causes \\
\hline technical & $\begin{array}{l}\text { - low energy efficiency of both } \\
\text { buildings and installations can lead to } \\
\text { insufficient heating of the building and } \\
\text { increased heating expenses; } \\
\text { - disposable income decreases due to } \\
\text { paying high energy charges as a } \\
\text { consequence of higher energy } \\
\text { consumption. }\end{array}$ & $\begin{array}{l}\text { These occur when: } \\
\text { - the place of residence has a low level } \\
\text { of energy efficiency, and maintaining } \\
\text { the heating standard is difficult; } \\
\text { — the heating system malfunctions, } \\
\text { being unable to heat the building; } \\
\text { - the household is equipped with } \\
\text { energy-inefficient devices, including } \\
\text { light bulbs, household appliances, and } \\
\text { consumer electronics. }\end{array}$ \\
\hline economic & $\begin{array}{l}\text { - energy arrears and energy source } \\
\text { access cut-off, reduce energy bills; } \\
\text { - the inability to cover necessary } \\
\text { energy expenses from the household } \\
\text { budget. }\end{array}$ & $\begin{array}{l}\text { These occur as a result of: } \\
\text { - deprivation of economic resources; } \\
\text { — mismanagement of the household } \\
\text { budget and related difficulties in } \\
\text { meeting housing expenses. }\end{array}$ \\
\hline $\begin{array}{lr}\text { resulting } & \text { from } \\
\text { attitudes } & \text { towards } \\
\text { efficient energy } & \text { enanagement }\end{array}$ & $\begin{array}{l}\text { - energy expenditures increase beyond } \\
\text { the household's acceptable level; } \\
\text { - disposable income does not cover } \\
\text { energy expenses. }\end{array}$ & $\begin{array}{l}\text { These occur when: } \\
\text { - energy devices are misused; } \\
\text { - knowledge of how to use the devices } \\
\text { effectively is insufficient; } \\
\text { - the household does not use energy- } \\
\text { efficient light bulbs; } \\
\text { - lack of thermal insulation of } \\
\text { buildings; } \\
\text { - not turning off electrical appliances } \\
\text { during periods of inactivity. }\end{array}$ \\
\hline
\end{tabular}

Source: Own work based on (Weglarz, Kubalski, Owczarek, 2014)

An analysis of the issue of energy poverty can already be found in the author's publication from 2020. At that time, however, the focus was on discussing the concept as a scientific category. She made an initial selection of statistic data, focusing on the country's situation as a whole. Currently, it can be concluded that the problem of energy poverty is the least recognized at the local level. The very question about the issue above raises emotions. While the local community recognizes the problem, in the absence of appropriate definitions and tools, it is often being analyzed in an intuitive manner. This article will refer to the author's survey covering Świętokrzyskie voivodeship, to which the author is related both professionally and through the family. The starting point for the presentation of conclusions will be the situation in Poland in the pre-pandemic period (Figure 1) and the diagnosis of probable causes of the phenomenon (Table 1). It will also be necessary to present measures in two views: absolute and relative.

According to Statistics Poland, for a household to be treated as energy poor in the scope of the country, it should meet, in relative terms, two main criteria: high costs of energy and low income, i.e., energy costs above the national median level and income below the officially defined poverty threshold. Another criterion is double median energy expenditure (2M), i.e., the share of actual energy expenditure in income that is higher than the double median of this value in the population. The ability to pay bills on time can also be examined to assess the level of poverty, as problems with arrears in paying energy bills or the inability to pay energy bills indicate a poor situation.

Additionally, a residential building with a leaking roof, moisture on/in walls, floors, foundations, rotting windows, or floors is a sign of problems with the state of the building. Insufficient thermal comfort should also be considered — this is the declared inability to sufficiently heat the house/apartment. 
As Table 1 shows, energy poverty is indeed multidimensional in nature. Therefore, it is necessary to prepare a comprehensive system of solutions leading to, e.g., increasing the energy efficiency of residential buildings, increasing the income of households considered poor to be able to pay their obligations on an ongoing basis, and educating residents in the field of energy management.

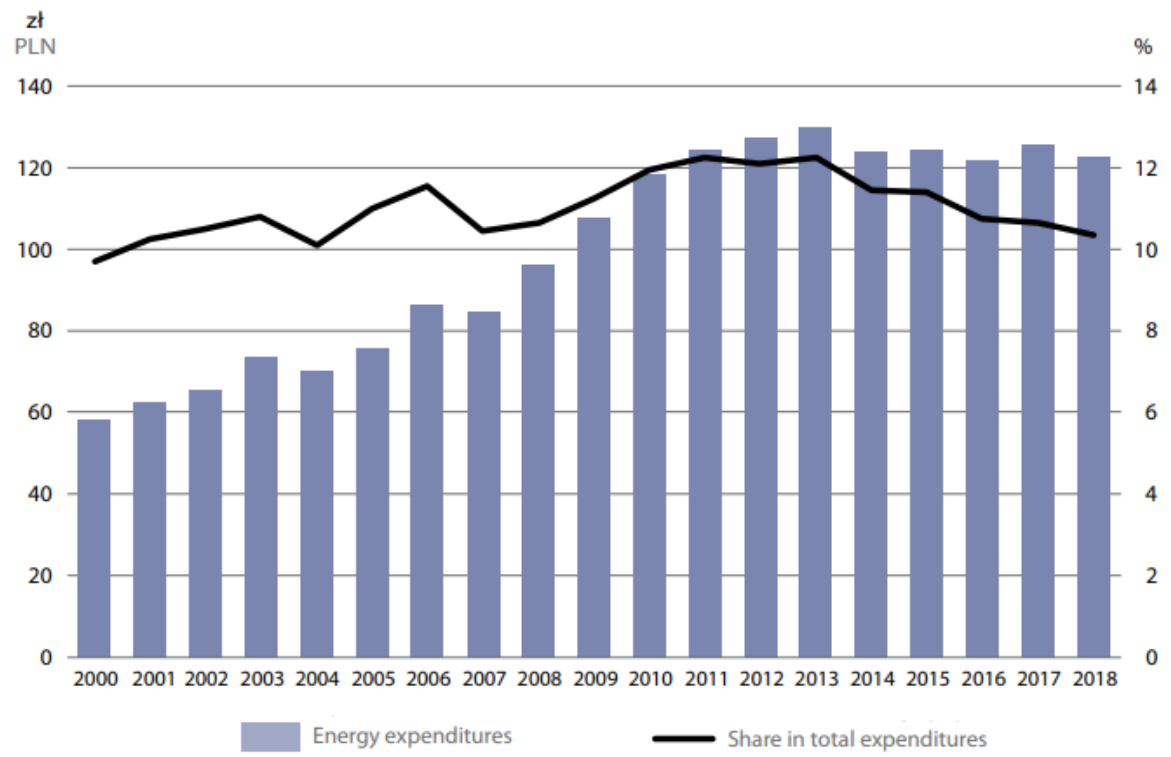

Figure 1: Average monthly expenditures for energy per capita and the share of energy expenditures in the total expenditures of households in the pre-pandemic period in Poland

Source: $\underline{\text { GUS, } 2020, \text { p. } 73}$

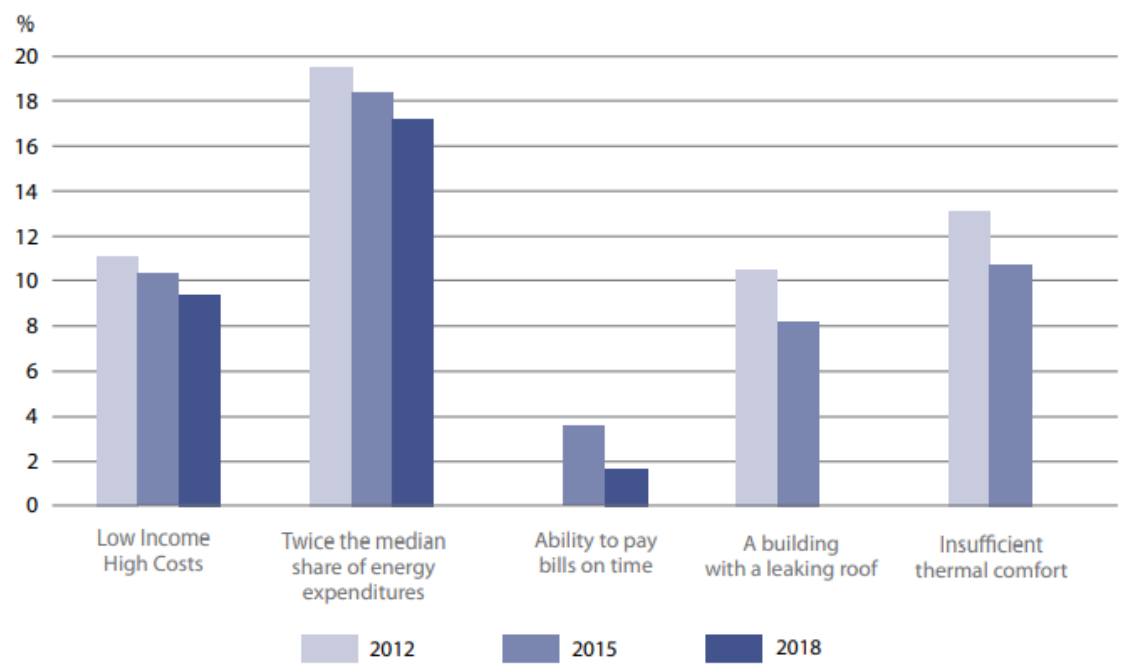

Figure 2: Measures of energy poverty

Source: Zużycie energii..., p. 74

Data from the pre-pandemic period indicate (Figure 1) that with respect to total expenditures, an irregular upward trend in the share of energy expenditures can be noticed (starting from 2002). It reached its highest value in 2011 (12.2\%). Between 2013 and 2018, there was a reduction in this share to 10.3\%, making it the lowest value since 2004 (Energy consumption, 2019, pp. 71-73). In the years presented, all of the listed measures of energy poverty had a downward trend, as presented in the graph (Figure 2). The double median energy expenditure had the highest value. In $2018,17.2 \%$ of households were considered energy poor (a decrease of 2.3 percentage points compared to 2012). Another of the indicators (high cost, low income) decreased from $11.1 \%$ in 2012 to $9.4 \%$ in 2018 . The main reason for this could be the improving material situation of the population (as a result of economic development and social policies). As for the ability to pay bills on time, only a small number (1.7\% in 2018) of households were unable to do so. The last two indicators relating to the technical and functional qualities of buildings, i.e., the poor state of buildings and insufficient thermal comfort, took similar values, which were $8.2 \%$ and $10.7 \%$, respectively, in 2018 .

The latest statistics indicate a $21.4 \%$ rise in energy poverty in Poland in 2020. This is a nearly $14 \%$ increase compared to the previous year. According to analysts, the values have been increased by, i.a., job loss and declining wages, especially among those with the lowest and middle incomes (PIE, 2021). Polish Economic Institute (PIE) pointed out that in Poland, 
the share of expenditure on electricity, gas, and other fuels in the structure of household expenditure is twice as high as the EU average.

\section{G. MYRDAL'S THEORY AND ENERGY POVERTY — AN OVERVIEW}

Gunnar Myrdal — Swedish economist, sociologist, politician, neo-institutionalist, and winner of the 1974 Nobel Prize in Economics born in 1899, emphasized the social aspects of economics in his work. He claimed that economics could be helpful in reducing social tensions. As a proponent of multi-stage socioeconomic reforms and mutual tolerance, he gave the economy a "human face," and his opinion on the role of science proves to be a helpful guideline for analysis. It is about the need to find the right direction for solutions and the necessary changes (Myrdal, 1969). Myrdal's concept of cumulative conditioning (a reference to Ragnar Nurkse's "circular process of cumulative causation") boiled down to the statement that every change initiates a sequence of secondary transformations. These, in turn, set the entire social system in motion. From an economic perspective, this can result in either increased overall prosperity or stagnation. However, as the author himself emphasized, the direction of development depends on a person's will, goals, and values (Myrdal, 1956, p. 335). Development in Myrdal's concept depends on variations in living conditions, attitudes, levels of production, and income but also closely relates to improvements in health and quality of life.

G. Myrdal as a proponent of state protectionism, believed that the role of the state is to conduct protectionist policy ("initiated growth") while preserving the foundations of capitalism (Nasiłowski, 1978, p. 280). As a humanist who was not indifferent to poverty, he called for combating poverty in the world. Also noteworthy is the ex-post and ex-ante analysis he proposes, which allows for the evaluation of phenomena in the future.

G. Myrdal's newly applied concept can also be proven to be helpful in the analysis of energy poverty. This is because it is a concept based on the assumption that the cause-and-effect chain of various events is circular. This means that a situation or event can be both a cause and effect. It is, therefore, a closed loop. "The vicious circle of poverty" described by Myrdal clearly shows that different aspects of economic status are mutually reinforcing and closely related. These include income level, employment, unemployment, or consumption. As rightly stated by Z. Gazda (2010, pp. 48-56), the issue of circular causation can be approached in two ways. Firstly, the causes and effects of an event or a process can be observed by analyzing the so-called winding up of a "spring," which results in the rebirth of these effects and causes after some time (and the correctly identified "initial cause" is to lead to the correct determining the causative factors). Second, a particular hypothesis can be assumed that proves that an "initial cause" does, in fact, exist. Moreover, it can be considered that it is the impetus for rebirth and accumulation in subsequent periods. Thus, the accuracy of the hypothesis will depend on the level of knowledge in the field of economic theory, economic history, and the history of economic thought. Moreover, the versatility of knowledge may allow driving the "wheel of causation."

\section{POVERTY AND ITS SCALE - BASED ON THE EXAMPLE OF THE ŚWIĘTOKRZYSKIE VOIVODESHIP}

A record of the minimum standards that should be met to maintain human well-being, as defined above, can be found in the UN-HABITAT document entitled The Right to Adequate Housing (UN-HABITAT 2009) ${ }^{1}$. Among them, two entitlements referring to the problem that can be qualified as energy poverty are found: availability of services, materials, facilities, and infrastructure (in particular, access to energy for cooking, heating, lighting, food storage) and habitability (in particular, protection from cold, moisture, heat, rain, wind and other structural hazards). Therefore, it remains to be seen how the situation looks like in Świętokrzyskie voivodeship, taking into account the mentioned current situation in the country. For the sake of the study, the population status of the voivodeship as of 31 December 2020 was assumed. Only adults, selected at random from the general population, were included in the study (296 adults in total, including 212 women). The results obtained will be presented at a $91 \%$ confidence level with a maximum error of $5 \%$.

In a subjective view of poverty, measures can be created based on a number of issues, such as the inability to maintain the desired room temperature, the quality of thermal insulation in buildings, or electricity bills. Although these do not provide a complete picture of the phenomenon, they give an approximation of its scale in a given area. Moreover, the analysis of the literature brings about a conclusion that energy poverty, which presents itself, i.a., in insufficient heating of buildings and, as a result, the development of harmful microorganisms, etc., leads to a higher probability of respiratory diseases, allergies (in the case of overly humid and fungal dwellings), hormonal disorders, cardiovascular disorders, deterioration of mental well-being (stress, anxiety, lowered mood) or a general decline in body’s immune function (Liddel, 2013).

\footnotetext{
${ }^{1}$ It should also be noted that during the UN Summit held on 25 September 2015 in New York, Poland signed a declaration of commitment to pursue the Sustainable Development Goals defined in a document entitled: "Transforming our world: the 2030 Agenda for Sustainable Development”. At least two of its goals that address the issue of energy poverty can be identified: ending poverty in all its forms everywhere (Goal 1) and ensuring access to affordable, reliable, sustainable and modern energy for all (Goal 7).
} 


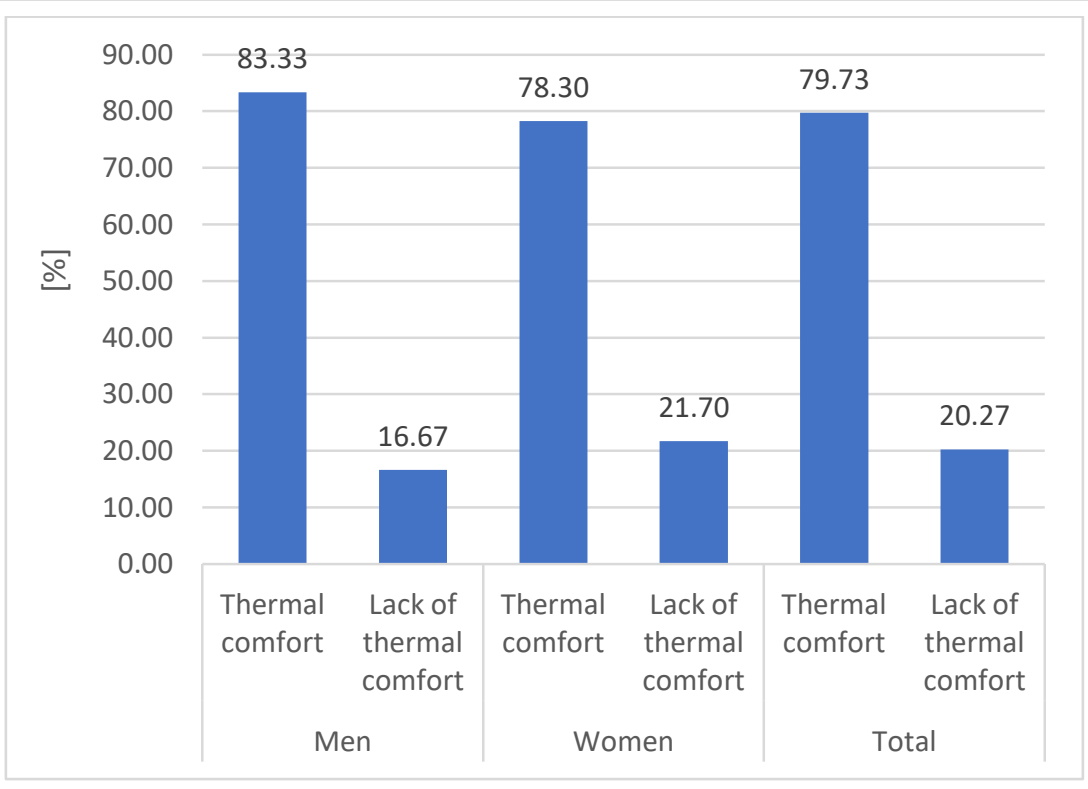

Figure 3: Thermal comfort by gender

\section{Source: Own work}

In the analysis of households in the Świętokrzyskie voivodeship, we will focus first on subjective indicators, showing that the phenomenon is experienced differently by women and men living in urban and rural areas.

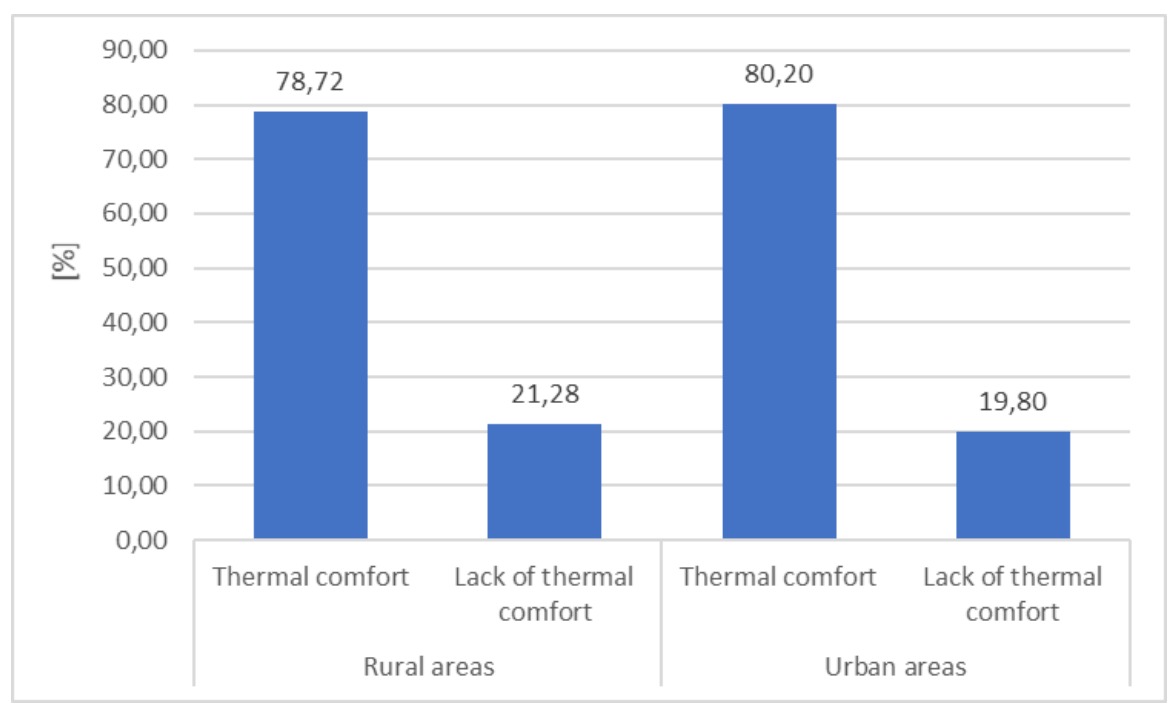

Figure 4: Thermal comfort by place of residence

\section{Source: Own work}

The subjective opinion on the optimal temperature providing thermal comfort can vary between people. In the first year of the pandemic (Figure 3), over $79 \%$ of the people surveyed in the voivodeship considered their need for thermal comfort to be met. Among the female respondents, $78.3 \%$ declared that their thermal comfort is maintained. 1 in 5 women reported a lack of thermal comfort during the study period. Among the male respondents, the data seem to paint a more optimistic picture. $83.33 \%$ of the men surveyed considered thermal comfort to be maintained, and only 1 in 6 men reported a lack of thermal comfort. The analysis further examined whether there were apparent differences in respondents' perceptions of thermal comfort by place of residence (Figure 4).

The analysis shows that the differences in perceived thermal comfort between urban and rural residents are subtle throughout the voivodeship. Although it might seem that it is easier to maintain thermal comfort in urban areas (due to access to district heating), only $1.48 \%$ more urban residents surveyed reported experiencing thermal comfort compared to the rest of the population living in rural areas. Approximately 1 in 5 rural and urban residents experienced a lack of thermal comfort.

Since the level of energy poverty is influenced by the inability to maintain the desired temperature inside residential buildings (lack of thermal comfort), it was analyzed which source of energy is dominant among people reporting lack of thermal comfort and which one is dominant in the group reporting experiencing thermal comfort (Figure 5). 


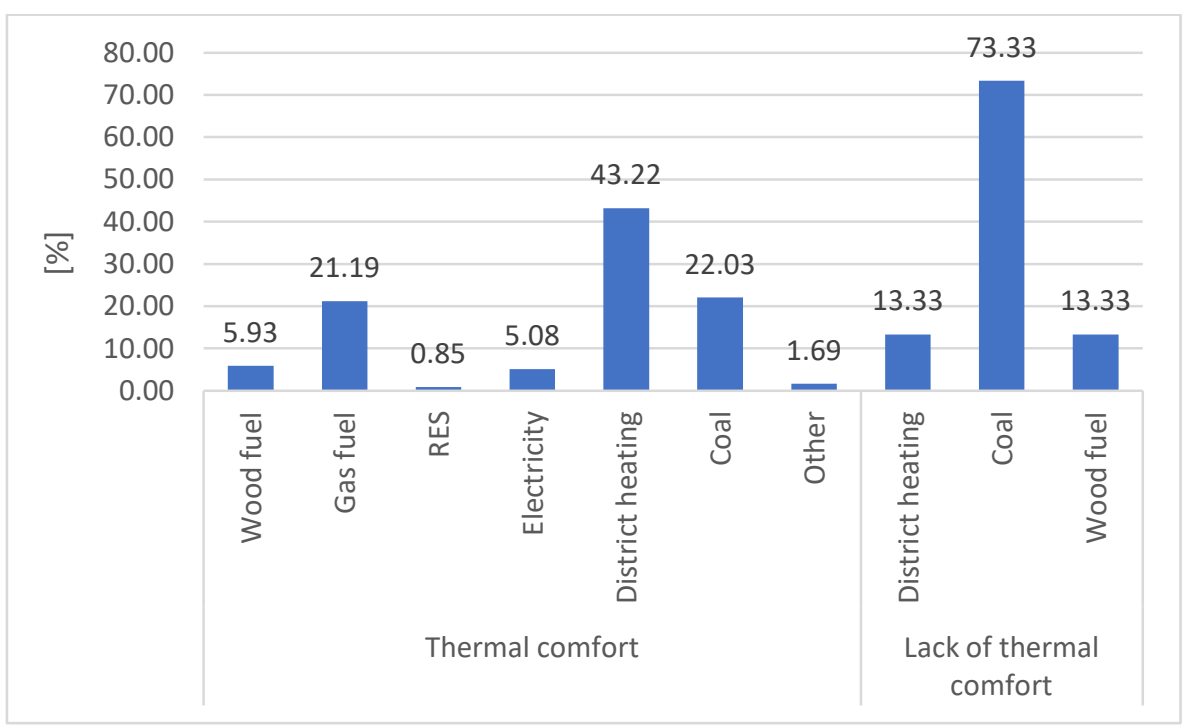

Figure 5: Energy sources and sense of thermal comfort

Source: Own work

The answers given by the respondents indicate that thermal comfort is primarily related to access to district heating. In second place are those households using coal-burning heating systems to maintain indoor temperatures $(22.03 \%$ of respondents). Perhaps surprisingly, a similar group of respondents having gas heating experience thermal comfort (21.19\%). Only 1 in 20 respondents experiencing thermal comfort used electricity to maintain an indoor temperature in the past year. This may mean that electricity is one of the more expensive commodities among the heating sources used by the voivodeship's residents. Less than $1 \%$ of respondents used renewable energy sources, which indicating that the installation price is too high in relation to their income.

The available reports on poverty in Poland for the pre-pandemic period indicated that the ratio of energy expenditure to income was one of the highest in Europe. Moreover, as recently as 2018, the Świętokrzyskie voivodeship was, alongside the Lubelskie, Małopolskie and Podkarpackie voivodeships, among the areas with the highest percentage of energy poverty (21-29\%). The survey therefore was aimed at determining how energy expenditure as a proportion of the voivodeship's total expenditure evolved during the first year of the pandemic.

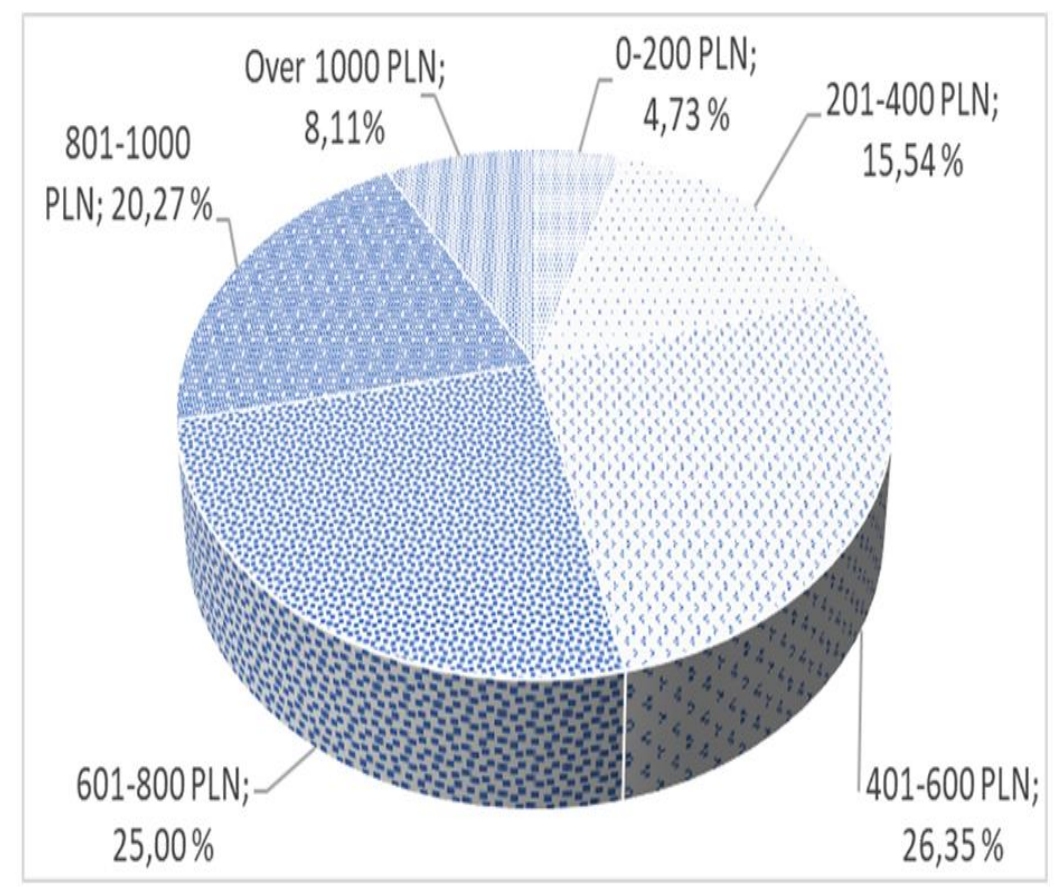

Figure 6: Structure of average monthly energy expenditure in the surveyed households

Source: Own work 


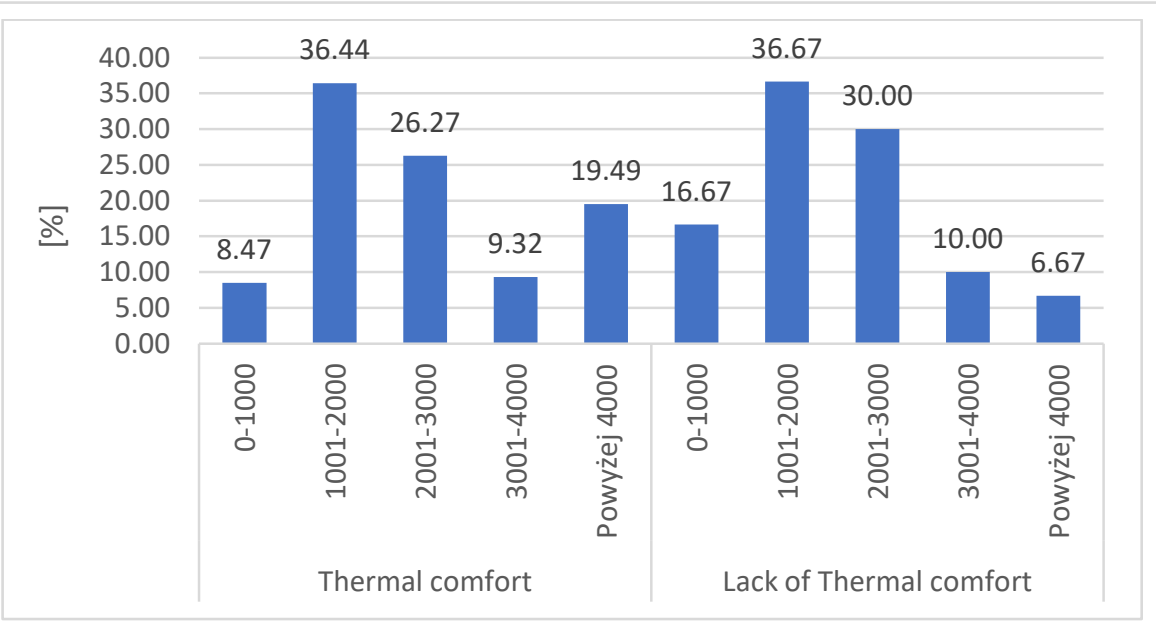

Figure 7: Average monthly income per capita in households taking thermal comfort or lack thereof into account

\section{Source: Own work}

Energy expenditure in the voivodeship exceeding PLN 1,000 per month concerned $8 \%$ of the surveyed households (Figure 6). Expenditures of PLN 800 - 1,000 were incurred by 1/5 of households in the analyzed period. The smallest expenditures for the indicated purposes, up to PLN 200, were reported by less than 5\% of the surveyed households. More than half of the surveyed households incurred monthly energy expenses in the range of PLN $400-800$., it can therefore be concluded that energy poverty is still linked to income poverty. Thus, in the next step, the average annual per capita income of households reporting maintenance of thermal comfort or lack thereof was examined. The results of the analysis are presented in Figure 7.

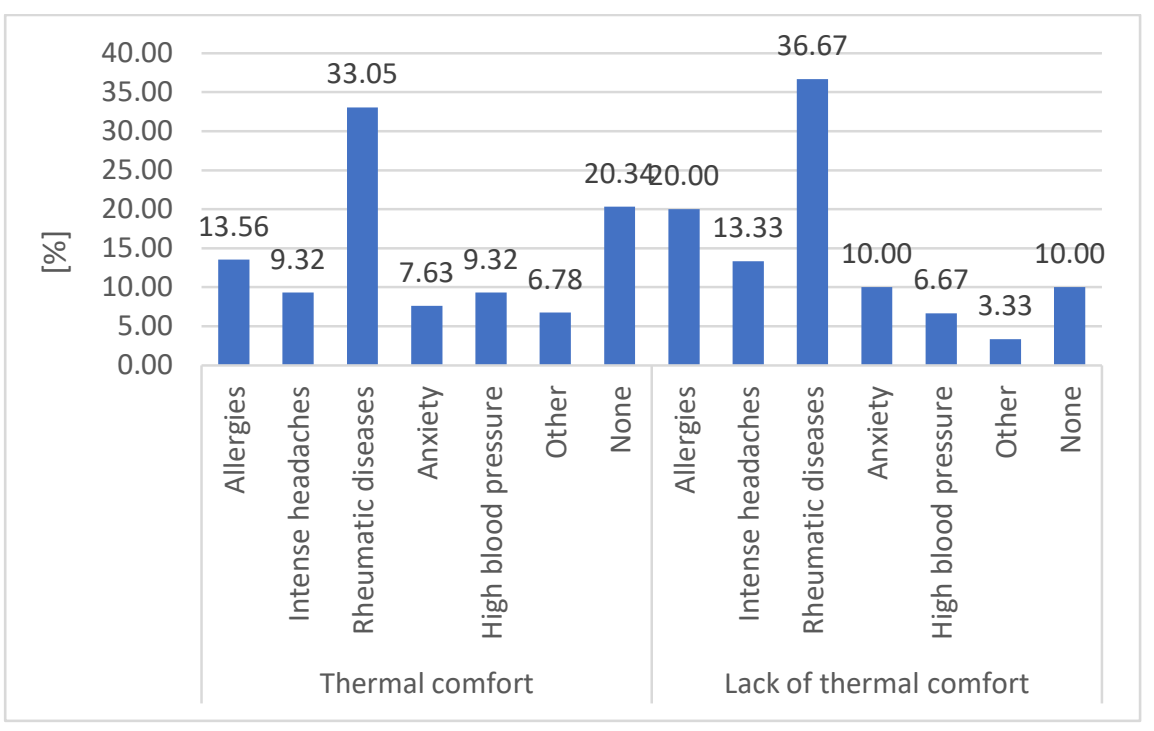

Figure 8: Illnesses declared by respondents taking thermal comfort or lack thereof into account

\section{Source: Own work}

According to the analysis, among those achieving thermal comfort in the past year, $36.44 \%$ of respondents indicated an average monthly income in the range of PLN 1,001 - 2,000 per person. 1 in 12 respondents declared an average income not exceeding PLN 1,000 per person. Only 1 in 5 respondents experiencing thermal comfort reported an average monthly income above PLN 4,000. The characteristics were very similar among those who indicated a lack of thermal comfort. The monthly income of $36.67 \%$ of them fell in the range of PLN 1,001 - 2,000. In this group, 1 in 6 respondents reported per capita income below PLN 1,000. Therefore, it can be concluded that the per capita income not exceeding PLN 2,000, with the current prices for energy sources, was too low to meet the energy needs of more than half of those declaring lack of thermal comfort. Moreover, it can be conjectured that the pandemic period, combined with the necessity of staying at home more often, may have exacerbated the negative consequences, especially in the group of people declaring lack of thermal comfort. The health consequences of this condition and which diseases were most prevalent in the study population were therefore examined (Figure 8).

The analysis shows that rheumatic diseases predominated in the group where thermal comfort was achieved $(33.05 \%$ of the respondents). 1 in 5 respondents did not indicate any illnesses that occurred during the first year of the pandemic- -1 in 8 reported allergies, and 1 in 10 - severe headaches. Anxiety states were declared by $7.63 \%$ of the subjects in this group. High blood pressure affected more than $9 \%$ of the respondents. Rheumatic diseases were prevalent in the group experiencing a lack of thermal comfort (thus, the low per capita income group) (almost $37 \%$ of respondents). Allergies 
affected 1 in 5 respondents, and anxiety was reported by 1 in 10. Compared to the group experiencing thermal comfort, in the second group, a higher percentage of people reported allergies, severe headaches or rheumatic diseases, and anxiety. However, the percentage of people reporting high blood pressure was $2.5 \%$ lower. Thus, while rheumatic diseases, according to the analysis, were not closely related to experiencing thermal comfort and dominate in both groups, better thermal conditions may have influenced blood pressure problems. Importantly, twice as many people reported a complete absence of diseases in the thermal comfort-satisfied group.

It can therefore be generalized that energy poverty contributes to poorer health, which in turn, in light of circular causation, results in an inability to cover higher energy expenses. This is because of the occurrence of additional health expenses, putting an extra burden on disposable income. Lower disposable income can lead to increased consumption of the cheapest energy sources (in the voivodeship, in the group of people suffering from energy poverty, it is coal). Therefore, it seems that an effective method of combating poverty in the voivodeship will be to increase the energy efficiency of buildings through their thermal modernization. This would improve thermal comfort and reduce energy expenditure.

For the completeness of the study of energy poverty in absolute terms, a link must be made between energy expenditure and household income. If the share of expenditures for the indicated purposes in disposable income exceeds a certain threshold, the household is suffering from energy poverty. In the author's study, an energy poverty threshold defined as at least $10 \%$ of energy expenditures relative to household disposable income was used. Exceeding this threshold will qualify the farm as suffering from energy poverty. The threshold adopted was implemented directly from the definition used in the UK.

The group above the $10 \%$ threshold included $31.08 \%$ of households that could be classified as suffering from energy poverty in the past year according to the previously indicated criterion. According to the high energy cost and lowincome criterion determined for the voivodeship, $10.14 \%$ of households were classified as suffering from energy poverty. The interpretation of this indicator requires a brief explanation. By design, this approach is to identify a group that has greater energy needs relative to other households in the population while having lower-income relative to other households. Thus, for a household to be classified as suffering from energy poverty according to the above definition, two conditions must be met simultaneously: household income must be below the poverty threshold $(60 \%$ of the median disposable income in the population) and model energy expenditures above the median in the population.

\section{CONCLUSION}

Energy poverty can affect:

1) Physical health in a negative manner, as a prolonged stay in a cold and humid environment, can lead to respiratory problems (including asthma) but also rheumatic, allergic, and other issues, as proven by the study.

2) Mental health in a negative manner (people living in energy poverty are prone to mental health problems, and poor housing conditions can cause anxiety leading to isolation or low self-esteem) as indicated by $10 \%$ of respondents in the Świętokrzyskie voivodeship experiencing lack of thermal comfort.

3) De-gradation of buildings (moisture in dwellings can be a direct cause of this, and inadequate insulation of windows, walls, or doors can increase heat loss).

It can also be concluded that the worse the housing conditions are, the more difficult it is to maintain the temperature at a proper level and thus stop the process of moisture accumulation in residential buildings.

Two other consequences of energy poverty should be added to the above. The first is excessive indebtedness, manifested in low-income households' inability to pay energy bills (electricity, heating, etc.) due to high health care bills. This, in turn, leads to further indebtedness. When energy bills are high, income that could be spent on other purposes (including food, medicine, or transport) is reduced. A poor energy standard of a building can result in increased energy consumption for heating but also have further consequences not covered by the study (such as increased carbon dioxide emissions).

It seems that currently, the scale of the phenomenon in the analyzed voivodeship may be even greater than indicated by the data. It is also worth noting note that actual household incomes may differ from those diagnosed due to the existence of the shadow economy (Wnukowski, 2020). Thus, it would not be insignificant to introduce more social programs aimed at improving the financial conditions of households and programs related to thermal efficiency and the development of RES.

\section{LIMITATION AND STUDY FORWARD}

The limitation of this work is the mere theoretical exploration of the above-mentioned issues related to energy poverty. Extending the study with practical aspects, including empirical examination of the impact of the socio-economic situation, alter the households' condition and energy poverty level in the świętokrzyskie voivodeship, may be considered the right direction for research.

\section{CONFLICT OF INTEREST AND ETHICAL STANDARDS}

The author states that there was no conflict of interest in any area during the whole paper writing and publication process. 


\section{ACKNOWLEDGEMENT}

The author would like to thank all other researchers for their comments, reports, and books, which were useful during his work (look: References). The text is the result of research conducted as part of the Research Project: SUPB.RN.21.109, Id: 538

\section{REFERENCES}

1. Chojnacka, K.J. (2020). Teoretyczny i praktyczny wymiar ubóstwa na przykładzie ubóstwa energetycznego /in:/ Problem bogactwa i ubóstwa w teoriach społeczno-ekonomicznych, B. Danowska-Prokop, A. Grabowski (Eds.), Katowice: Publishing House of the University of Economics in Katowice.

2. Gazda, Z. (2010). O zastosowaniu koncepcji „kumulatywnej, okrężnej przyczynowości” do kategorii wyboru ekonomicznego /in:/ Dokonania współczesnej myśli ekonomicznej — znaczenie kategorii wyboru w teoriach ekonomicznych i praktyce gospodarczej, Zagóra-Jonszta U. (Eds.), Katowice: Publishing House of the University of Economics in Katowice.

3. Herudziński, R., Boguszewski, T. (2018). Ubóstwo energetyczne w Polsce, Pracownia Badań Społecznych SGGW, Warszawa, Retrieved from: https://cire.pl/pliki/2/2018/ubostwo_energetyczne_w_polsce_ra port_03_09_2018.pdf, [accessed: 5 December 2021].

4. Liddel, C. (2013). The Benefits of Tackling Fuel Poverty. Mental Health Impacts and Why These Exist. Presentation from the "Roundtable on the Health \& Well-being Impacts of Energy Efficiency Improvements" workshop, Copenhagen.

5. Kubiczek, J., Hadasik, B. (2021). Challenges in reporting the COVID-19 spread and its presentation to the society. Journal of Data and Information Quality, 13(4), 1-7. https://doi.org/10.1145/3470851

6. Kumar, A., Nayar, K. R. (2020). COVID-19 and its mental health consequences. Journal of Mental Health 30, 1-2. https://doi.org/10.1080/09638237.2020.1757052.

7. Miazga, A., Owczarek D. (2015). Dom zimny, dom ciemny, czyli ubóstwo energetyczne w Polsce (English title: It's cold inside - energy poverty in Poland), Institute for Structural Research, Warsaw, Retrieved from: https://ibs.org.pl/publications/dom-zimny-dom-ciemny-czyli-ubostwo-energetyczne-w-polsce/ [accessed: 5 May 2021]

8. Myrdal, G. (1956), An International Economy, New York.

9. Myrdal, G. (1969), Objective in Social Research, New York.

10. Myrdal, G. (1970), Objectivity on Social Research, London: Duckworth.

11. Nasiłowsk,i M. (Eds.) (1978), O teoriach rozwoju współczesnego kapitalizmu, Warszawa: PWN.

12. PIE: Drastyczny wzrost ubóstwa energetycznego $w$ Polsce, Retrieved from: https://biznes.interia.pl/finanse/news-pie-drastyczny-wzrost-ubostwa-energetycznego-w-polsce,nId,5237464 [accessed 19 December 2021]

13. Stępniak, A., Tomaszewska, A. (2014), Ubóstwo energetyczne a efektywność energetyczna. Analiza problemu $i$ rekomendacje. Institute for Sustainable Development, Retrieved from: https://docplayer.pl/10089876-Ubostwo-energetyczne-a-efektywnosc-energetyczna-analiza-problemu-irekomendacje.html [accessed: 5 January 2022]

14. Węglarz, A., Kubalski, G., Owczarek, D. (2014), Propozycje mechanizmów wsparcia procesu przeciwdziałania zjawisku ubóstwa energetycznego w Polsce, Institute for Sustainable Development.

15. Wnukowski, D. (2020), Konsekwencje epidemii koronawirusa dla gospodarki UE. Bulletin of the Polish Institute of International Affairs, 45(1977). Retrieved from: https://pism.pl/upload/images/artykuly/4e306947c806-4ff6-873d-f99fe91ced02//1584623079453.pdf (accessed 01.02.2022).

16. Energy consumption in households in 2018 (2020), Statistical analyses, Warsaw.

17. Zużycie energii w gospodarstwach domowych w 2018 r. (2019), GUS, Warszawa, Retrieved from: https://stat.gov.pl/files/gfx/portalinformacyjny/pl/defaultaktualnosci/5485/2/4/1/zuzycie_energii_w_gospodars twach_domowych_w_2018.pdf [accessed: 19 December 2021]. 